\title{
A Papist in a Protestant Age: The Case of Richard Bennett, 1667-1749
}

\author{
By Beatriz Betancourt Hardy
}

\section{$\mathrm{T}$} particularly crowded in the late summer and early fall of 1749 . At the plantation house near the landing, Richard Bennett III lay dangerously ill, as the Maryland Gazette informed its readers on October 4. Bennett's relatives and friends flocked to the house, streaming in and out of Bennett's room and milling around outside. Meanwhile, the eighty-twoyear-old Bennett struggled to conduct business from his bed. He grew progressively weaker and finally died on October 11 . The Maryland Gazette eulogized Bennett as "the greatest Trader in this Province" and observed that "by his Death, the poor and needy have lost their greatest Friend and Benefactor." 1

At the time of his death, Richard Bennett was the owner of nearly fifty thousand acres and a vast personal estate; some considered him the richest man in North America. ${ }^{2}$ He traded with Great Britain, the West Indies, and the other American colonies. He lent a large amount of money to a large number of people. ${ }^{3}$ By birthright, he should have been

\footnotetext{
${ }^{1}$ Bennett's obituary appeared in the Annapolis Maryland Gazette on October 18, 1749. Testimony regarding the last days of Bennett's life can be found in Testamentary Proceedings, Liber 34, folios 290-301, and Liber 35, folios 29-45 (Maryland State Archives, Annapolis; hereinafter MSA). All dates have been modernized. I would like to thank the Maryland State Archives, the Maryland Historical Society, and the history departments of the University of Maryland at College Park and the Johns Hopkins University for jointly sponsoring the Maryland History Fellowship, which I held when I wrote this essay. An earlier version of this essay won the 1991 Colonial Essay Prize, sponsored by the Colonial Society of Pennsylvania and the Philadelphia Center for Early American Studies. I also wish to thank Lois Carr, Ronald Hoffman, Emory Evans, Alison Olson, Jean Russo, John Brooke, Alice Reagan, and Stephen Hardy for their help and comments.

${ }^{2}$ See below for a discussion of Bennett's landholdings. The Annapolis Maryland Gazette of November 8, 1749, and Gentleman's Magazine, XX (January 1750), 43 called Bennett the richest man in America. Stead Lowe, an Englishman who had moved to Maryland, estimated Bennett's worth at $£ 150,000$ sterling in 1748 . See Stead Lowe to brother, July 20,1748, Drury-Lowe Papers, Dr C 1/2 (Department of Manuscripts and Special Collections, Hallward Library, University of Nottingham, University Park, England).

${ }^{3}$ According to Paul G. E. Clemens, "Bennett lent more money to more people than any other inhabitant of the Eastern Shore." See The Atlantic Economy and Colonial Maryland's Eastern Shore: From Tobacco to Grain (Ithaca and London, 1980), 124.
}

Ms. HARDY is an assistant professor of history at Coastal Carolina University. 
a political officeholder, a member in good standing of the native political elite described by David W. Jordan: his father had been an assemblyman; his stepfather, Speaker of Maryland's lower house; his grandfather, governor of Virginia; and all of his younger half brothers, members of the Maryland Council. ${ }^{4}$ And yet Richard Bennett himself was never on the Council, never elected to the lower house, and never served as a justice of the peace; for the last thirty-one years of his life, he could not even vote. Richard Bennett, unlike his officeholding male relatives, was a Catholic. In 1689, just as he reached adulthood, the position of Catholics in Maryland began to deteriorate as Catholics lost the right to hold office; in 1704 they lost the right to worship publicly, teach school, and seek converts; in 1718 they lost the right to vote. ${ }^{5}$

Historians of the colonial Chesapeake commonly portray the gentry as political, social, and financial leaders. However, from the work of Aubrey C. Land in the 1960s to the more recent work of Allan Kulikoff, historians have not fully recognized how the experience of Quaker and Catholic members of the gentry differed from that of Anglicans. ${ }^{6}$ Catholics and Quakers were excluded from the traditional forms of political power by which Kulikoff believes the gentry cemented their control: they could not serve as justices of the peace or as assemblymen, and after 1718 the Catholic gentry were denied the right to vote. ${ }^{7}$ Catholics and Quakers were also prohibited from holding other governmental offices and practicing law-activities that proved very profitable for their Anglican counterparts, as Land demonstrates. ${ }^{8}$ Finally, they were ineligible to serve as Anglican vestrymen and to participate in the whole ritual of church attendance that Rhys Isaac describes. ${ }^{9}$

4 David W. Jordan, Foundations of Representative Government in Maryland, 1632-1715 (Cambridge, Eng., and other cities, 1987), especially 147-57; and Edward C. Papenfuse et al., eds., A Biographical Dictionary of the Maryland Legislature, 1635-1789 (2 vols. paged consecutively; Baltimore and London, 1979-1985), I, 129-30, and II, 534-45 (hereinafter cited as BDML).

5 William Hand Browne et al., eds., Archives of Maryland (72 vols., Baltimore, 1883-1972), VIII, 69 and 107, XXVI, 340-41, and XXXIII, 287-89; see also XXVI, 539 and 583-90 (hereinafter cited as Arch. Md.).

- For example, see Aubrey C. Land, "Economic Base and Social Structure: The Northem Chesapeake in the Eighteenth Century," Journal of Economic History, XXV (December 1965), 639-54; Allan Kulikoff, Tobacco and Slaves: The Development of Southern Cultures in the Chesapeake, 1680-1800 (Chapel Hill and London, 1986); and Trevor Graeme Bumard, "A Colonial Elite: Wealthy Marylanders, 1691-1776" (Ph. D. diss., Johns Hopkins University, 1988). A broader formulation of the role of Maryland gentry is found in Ronald Hoffman's fine article, "Marylando-Hibemus': Charles Carroll the Settler, 1660-1720," William and Mary Quarterly, 3d Ser., XLV (April 1988), 207-36.

${ }^{7}$ Kulikoff, Tobacco and Slaves, 281-89.

"Land, "Economic Base," 651-52. Catholics were able to practice in the equity courts but not in the common-law courts.

Kulikoff, Tobacco and Slaves, 234-37; and Rhys Isaac, The Transformation of Virginia, 17401790 (Chapel Hill, 1982), 60-65. 
Despite their exclusion from these traditional gentry activities in church and state, Catholics and Quakers were undeniably members of the gentry. Their experiences suggest that historians should refocus the study of the formation and functions of the gentry class by de-emphasizing formal institutional activities such as government officeholding and emphasizing informal or noninstitutional factors such as economic and social leadership and kinship ties. Political power and officeholding are perhaps the most obvious and easily measurable gentry attributes: the records of courts and legislatures indicate who served in office and what they did. Concentration on the Catholic gentry requires further, less obvious research into alternative ways in which the gentry exercised leadership and power and compels an acknowledgement of the diversity of gentry experiences.

Even within the Catholic gentry itself, diversity existed as the gentry adapted to its legal disabilities in various ways. At one extreme was resistance and even a sort of tribalism. Charles Carroll the Settler (16601720) and his son Charles Carroll of Annapolis (1702-1782) represent this position: they bitterly resisted the political disabilities, continued to worship as Roman Catholics, and had few family ties to Protestants. In fact, one foreign traveler to Maryland in 1765 alleged that the younger Carroll kept "but very litle Company owing perhaps to his Distaste to the protestants." ${ }^{10}$ At the opposite end of the spectrum was total integration into the Protestant world. Doctor Charles Carroll (1691-1755), a member of a different branch of the Carroll family, took the most accommodating position possible: he converted to Anglicanism in the late 1730s, raised his children as Anglicans, and became the leader of the antiCatholic faction in the lower house in the early 1750 s. ${ }^{11}$ Many Catholic gentlemen adopted positions between the two extremes of resistance and integration. For example, Henry Darnall III (1703-fl. 1783) converted to Anglicanism and became attorney general of the colony, but his family remained Catholic. ${ }^{12}$ Richard Bennett occupied yet another intermediate position: never disavowing his Catholic faith, he enjoyed access to political power through his close family ties to a large number of politically powerful Protestants. His tremendous wealth gave him added influence, especially in economic matters. The life of Richard Bennett provides a useful case study of how the Catholic gentry adapted to legal disabilities.

${ }^{10}$ Hoffman, "'Marylando-Hibernus'," 207-36; and "Joumal of a French Traveller in the Colonies, 1765, II," American Historical Review, XXVII (October 1921), 74.

${ }^{11} B D M L, \mathrm{I}, 193-94$ and 196.

${ }^{12}$ Arch. Md., LII, 159. 
Richard Bennett III was born in September 1667, the second child and first son of Henrietta Maria Neale and Richard Bennett II, who had died four months before his son's birth. The marriage of Bennett's parents represented the union of two families of opposing political and religious persuasions. Bennett's paternal grandfather, Richard Bennett I, was a Puritan who had taken control of Maryland on behalf of Oliver Cromwell and Parliament; while Bennett was parliamentary commissioner for Maryland during the $1650 \mathrm{~s}$, Catholics temporarily lost the right to practice their religion. ${ }^{13}$ Bennett's maternal grandfather was also a prominent man, but in a vastly different context: James Neale I was a Maryland Catholic who, during the 1650s, had served as ambassador to Spain and Portugal on behalf of Charles II and James, Duke of York, before returning with his family to Maryland in $1660 .{ }^{14}$

In 1669, two years after her first husband's death, Henrietta Maria Bennett married Philemon Lloyd I, a prominent Anglican politician from Talbot County. Lloyd served in the lowerhouse from 1671 until one yearbefore his death in 1685 and was Speaker from 1676 through $1684 .{ }^{15}$ Philemon Lloyd's death left eighteen-year-old Richard Bennett as the oldest male in the Lloyd household. Henrietta Maria Lloyd had raised her two Bennett offspring as Catholics, attending Mass in the Lloyd house and at the chapel in nearby Doncaster-Town whenever a Catholic priest visited the small Catholic community in Talbot County. ${ }^{16}$ Philemon Lloyd, however, stipulated in his will that his ten children be raised as Protestants, and his widow carried out his wishes. Living in a Protestant-Catholic household provided the Bennett and Lloyd children with practical experience in religious toleration. ${ }^{17}$

After coming of age in 1688, Richard Bennett entered the business world. A substantial inheritance from his paternal grandfather provided him with the means to pursue a career as a merchant. Bennett plunged into trade, both on his own and jointly with his mother, and bought shares

${ }^{13} B D M L, I, 129-30$. Richard Bennett II wrote his will on January 1, 1666, before the birth of his eldest child, Susanna Maria Bennett. The will was proved May 6, 1667. Richard Bennett Jr.'s will, Provincial Wills, Liber 1, folio 278, MSA.

${ }^{14}$ BDML, II, 609.

is Ibid., 541 .

${ }^{16}$ Henrietta Maria Lloyd's additional inventory in 1697 included a "parcell of Church Stuff," which is how appraisers often described items such as chalices. See Inventories and Accounts, Liber 22, folio 213, MSA. John Londey in 1693 had left one-third of his personal and real estate, including 1,100 acres, to the Doncaster or Wye-Town chapel, and the remainder to Henrietta Maria Lloyd. See Wills, Liber 2, folio 259, MSA. Henrietta Maria Lloyd in tum bequeathed 300 of her own acres and all the land that Londey had left her to the Doncaster chapel in her 1697 will. See Wills, Liber 7, folio 252, MSA.

${ }^{17} B D M L, I I, 541$; Lloyd specified that the children were to be brought up as Protestants until they were old enough to "Judge what is most consunant to the good will of Almighty God," will dated May 27,1682 , and proved July 16, 1685, Provincial Wills, Liber 4, folio 186, MSA. 
in at least two ships. He also began amassing land, adding 2,300 acres in 1692 to the 1,300 acres that he already owned. ${ }^{18}$

As Richard Bennett began his adult life, events in Maryland took a turn that would adversely affect the position of all Catholics, both rich and poor. During the 1680 s many colonists had grown increasingly discontented with the proprietary rule of Charles Calvert, the third Lord Baltimore, who was a Catholic, and some of the leading Protestants felt excluded from Lord Baltimore's primarily Catholic inner circle. When news reached Maryland of the Glorious Revolution in England, these discontented elements seized the opportunity to overthrow Lord Baltimore. The Protestant Associators, as they styled themselves, ousted Catholics from all civil and military posts; many Protestants and virtually all Catholics opposed the Associators. ${ }^{19}$ A royal governor arrived in 1692 to take control of the government for the Crown, although the Calverts retained their proprietary rights to the land.

In August 1689, in an effort to consolidate their position, the Protestant Associators sent thirty to forty men to seize arms and ammunition from the Eastern Shore's two leading Catholics, Peter Sayer and Bennett's mother Henrietta Maria Lloyd. ${ }^{20}$ Just over two years later, in 1692, frustrated perhaps by the treatment of his mother and his own exclusion from office, Bennett demonstrated his disrespect for the new government at the February session of the Talbot County Court. Bennett and several other men engaged in four days of drunken revelry and feasting: they tied up a horse inside the courtroom, rode their own horses up and down the magistrates' bench, and put themselves into the pillory-all the while

\footnotetext{
${ }^{18}$ Richard Bennett I made his grandson Richard Bennett III his heir-at-law. See the will of Governor Richard Bennett, dated March 15, 1674, and proved August 3, 1676, in Virginia Will Records From the Virginia Magazine of History and Biography, the William and Mary College Quarterly, and Tyler's Quarterly (Baltimore, 1982), 672-74. No inventories exist for the estates of either Richard Bennett I or Richard Bennett II. In addition, the land records for Nansemond County, Virginia, do not survive, so it is impossible to determine how much land Richard Bennett I left to his grandson. Evidence of Bennett's participation in the administration of his stepfather's estate and his trading activities can be found in Testamentary Proceedings, Liber 16, folio 132, and Inventories and Accounts, Liber 21, folio 218, MSA. Bennett in 1697 owned a 120-ton ship with Robert Grayson and others; see Arch. Md., XXV, 600. He also owned a 300-ton square-stem ship, the Speaker of London, with Anthony Stratton, Nicholas Smith, Henry Wolstenholme, John Bennett, and Richard Carter, see Naval Officer Shipping List, Port of Annapolis, 1699, British Public Record Office, Kew (hereinafter PRO), Colonial Office (CO), Class 5 (America and West Indies), Volume 749, part 5 , folios 217-18 (photocopy at Library of Congress).

${ }^{19}$ Lois Green Carr and David William Jordan discuss the causes of Coode's Rebellion, as the uprising of the Protestant Associators was called, in Maryland's Revolution of Government, 16891692 (Ithaca, N.Y., and London, 1974), especially pp. 47, 187-92, 194-98, and 221-22. See also Richard A. Gleissner, "Religious Causes of the Glorious Revolution in Maryland," Maryland Historical Magazine, LXIV (Winter 1969), 327-41. "Articles of Surrender," Arch. Md., VIII, 107.

${ }^{20}$ Peter Sayer to Lord Baltimore, December 31, 1689, Arch. Md., VIII, 158-62. On February 28, 1694, the Council ordered the private arms seized from Catholics in 1689 to be retumed. Arch.Md., $\mathrm{XX}, 224$.
} 
mocking the new government. Bennett's fellow revelers included Samuel Withers, the sheriff of Talbot County; John Lillingston, an Anglican minister; Thomas Smith, possibly a Catholic priest; William Coursey, a large landowner later elected to the lower house; and seven others. After investigating the incident, the Council of Maryland ordered Lillingston's arrest as the ringleader but released him without a trial. ${ }^{21}$ While this incident may have been a result of simple drunken rowdiness, it also indicates that Bennett's social network included both Catholics and prominent Protestants.

By the mid-1690s, the period of resistance to the Glorious Revolution was coming to an end. Eastern Shore Catholics lost their two primary leaders when Peter Sayer and Henrietta Maria Lloyd died in 1697. Leadership passed to Richard Bennett and his brother-in-law Charles Blake. Bennett acted as trustee for the lands bequeathed by his mother to the priests who served the Eastern Shore. ${ }^{22}$ Just one year later, in 1698, Peter Sayer's widow Frances also died; in her will, she bequeathed the chapel in Doncaster-Town to Bennett and Blake and ordered that another chapel be built over her husband's grave near the Sayer house. Her residuary legatee was her niece Elizabeth Rousby, whom Bennett married in late 1700. Like her husband, Elizabeth Rousby had grown up with a Protestant father and a Catholic mother. Soon after their marriage, the Bennetts moved into the Sayer house, which Elizabeth had inherited. ${ }^{23}$

Henrietta Maria Lloyd's death helped to establish Richard Bennett as a leader of both the Catholic community and the mostly Protestant Lloyd family. He and his half brother Philemon Lloyd II became the primary executors of their mother's will and the guardians of their younger siblings. ${ }^{24}$ Bennett also administered the Maryland estate of his

${ }^{21}$ Arch. Md., VIII, 371-74 and 378; and for Coursey, see BDML, I, 237. The other men involved were Richard Macklin, Joseph Lambert, Joseph Greene, John Hinson Sr., Michael Earle, Thomas Hinds, and John Lamb. In 1693 the Council ordered the arrest of Peter Sayer of Talbot County for conspiring against the govemment and lodging Thomas Smith, who faced arrest on charges of being "a Romish Preist coming from Cannida under the Dominion of the French King into this Province in the nature of a Spy." Arch.Md., VIII, 373, 503 (quotation).

${ }^{22}$ Blake was Peter Sayer's nephew and had married Bennett's half sister Henrietta Maria Lloyd II. Bennett finally conveyed these lands to Richard Molyneux, S. J., on August 12, 1745, at a time when he was quite ill. See Queen Anne's County Land Records, Liber RTC, folio 318, MSA.

${ }^{23}$ Frances Sayer's will, dated May 26, 1698, proved September 27, 1698, Wills, Liber 6, folio 166-67, MSA; and Peter Sayer's will dated August 29, 1697, proved November 2, 1697, Wills, Liber 7, folios 334-35, MSA. For evidence of Bennett's marriage, see Testamentary Proceedings, Liber 18B, folio 39, MSA.

${ }^{24}$ Henrietta Maria Lloyd I also appointed her mother Anne Neale and brother Anthony Neale to be executors, but they did not join in the administration. Her brother James Neale II did join as an executor and guardian, but he lived in Charles County and probably was not involved in the day-today administration. Wills, Liber 7, folios 252-54; and Testamentary Proceedings, Liber 17, folios 3 and 93, MSA. 
step-grandfather Edward Lloyd I of London, which was a further indication of his standing within the Lloyd family. ${ }^{25}$

In addition to the changes that Henrietta Maria Lloyd's death brought to Bennett's family and religious life, herdeath also accelerated Bennett's business career. Bennett became the quintessential merchant planter, not only trading and accumulating land but also lending money. Beginning by 1698 and continuing for the rest of his life, Bennett made many loans. He made his first mortgage loan in 1698; by 1718 he had lent $£ 1,078.9 .8$ sterling, $£ 100$ current silver money, and 40,294 pounds of tobacco on fourteen mortgage loans. ${ }^{26}$ Although Bennett's own financial papers did not survive, court records indicate that the bulk of his lending occurred on trading accounts or through bonds. Many of Bennett's loans were relatively small, but a few were quite large. For example, in 1706 the Provincial Court awarded Bennett $£ 400$ sterling due on a debt from Philemon Hemsley, a justice of the peace in Talbot County. The next year Bennett received awards of $£ 1,000$ sterling each for debts due from Thomas Taylor and William Sharpe, merchants in Talbot County; in 1708 the Provincial Court awarded Bennett $£ 600$ sterling from the estate of Robert Smith, a former member of the Council, in payment of Smith's debt to Bennett. ${ }^{27}$ By 1718 Bennett had filed twenty-three suits in Provincial Court to recover debts and had received awards worth $£ 3,628.9 .4$ sterling, $£ 91.14$ current money, and 127,654 pounds of tobacco. ${ }^{28}$

Bennett's landholdings also grew, tripling from 7,798 acres in 1700 to 22,679 acres ten years later, the vast majority of which he had purchased.

\footnotetext{
${ }^{25}$ Edward Lloyd I of London had died in 1696. Richard Bennett was his step-grandfather's greatest creditor in Maryland. Grace Lloyd, widow of Edward Lloyd of London, appointed Bennett her husband's administrator in Maryland and gave all her estate in Maryland to her kinsman Richard Bennett. Testamentary Proceedings, Liber 17, folios 3, 131-32, MSA; and Provincial Court Land Records, Liber WRC1, folio 838, MSA. The Prerogative Court of Canterbury granted letters of administration to Bennett in September 1697 to administerhis mother's estate in England. See Peter Wilson Coldham, comp., American Wills and Administrations in the Prerogative Court of Canterbury, 1610-1857 (Baltimore, 1989), 190.

${ }^{26}$ Bennett's mortgage activities can be traced in the land records of each county and in the Provincial Court Land Records at MSA. Bennett was not nearly as active in lending on mortgages as Charles Carroll the Settler, who had made fifty-four mortgage loans worth $£ 6,978$ sterling from 1700 to 1720 . See Hoffman, “'Marylando-Hibernus'," 223.

${ }^{27}$ The particular cases cited can be found in Provincial Court Record, Liber PL1, folios 110-11, 187, 197-99, and 271-72. The court records identified Sharpe and Taylor as merchants; and for Hemsley and Smith, see BDML, I, 430 and II, 748.

${ }^{28}$ For Bennett's suits to recover debts, see scattered cases in Provincial Court Record, Libers TL3, TB2, PL1, PL2, PL3, TP2, IO1, and VD2, at MSA. In the same years, Charles Carroll the Settler filed sixty suits, winning awards of $£ 1,712$ sterling, $£ 100$ current money, and over 2,300 pounds of tobacco. See Hoffman, "Marylando-Hibemus'," 224.
} 
Some of the land Bennett leased out to tenants; some he farmed with overseers and slaves; and some undoubtedly remained fallow. ${ }^{29} \mathrm{He}$ also bought two mills in Talbot County-Wye Mill in 1705 and Randall's Mill in $1708 .^{30}$

Judging from his moneylending and land acquisitions, Bennett must have had access to substantial capital. He probably did not often borrow money himself; there was only one lawsuit to recover debts entered against Bennett in Provincial Court. ${ }^{31}$ Inheritance, trading, and shipping undoubtedly supplied some capital, and presumably, the crops grown by his slaves and tenants were profitable. ${ }^{32}$ Another major source of capital was the right to the quitrents of Maryland, which, in 1699, Bennett and his friend and fellow Catholic James Heath leased from the Calvert family for eight years. ${ }^{33}$

Despite his immersion in business, Bennett joined with prominent Western Shore Catholics to protect Catholic interests from attacks by the legislature and the governor. While neither Catholics nor Quakers had favored the establishment of the Church of England in Maryland during

\footnotetext{
${ }^{29}$ In the decade from 1701 to 1710 , Bennett bought 11,443 acres and two lots in Doncaster-Town, patented 1,909 acres, and foreclosed on 929 acres. Bennett's land transactions can be found in the land records of the various counties and the Provincial Court Land Record at MSA. It is not possible to determine the number of slaves that Bennett owned overall. He maintained a number of quarters; and the 1733 list of taxables for Talbot County includes five quarters owned by Bennett with a total of thirty-six taxables. In 1740 he was responsible for 117 taxables in Kent County; and the 1749 tax list for Kent County listed thirty-five taxables at one of Bennett's quarters, including thirty slaves. James Paul Heath, the son of Bennett's former partner James Heath, supervised Bennett's land in Cecil County, which he rented to tenants who raised tobacco. See A List of Taxables, Talbot County Anno Dom 1733, Maryland State Papers, Scharf Collection, 19999 118/49, MSA; Kent County Levy Book, 1722-1743, folio 321, 8762, MSA; Kent County Tax List, 1749, Secretary in Maryland, 19839-24, MSA; and Estate accounts of James Paul Heath, 1743, Lloyd Papers, MS. 2001 (Maryland Historical Society, Baltimore; hereinafter MHS).

${ }^{30}$ Bennett leased Wye Mill in 1706 to William Sweatnam. See Talbot County Land Records, Liber RF9, folio 313; Liber RF10, folio 55; and Liber RF11, folio 46, MSA.

${ }^{31}$ There were, in fact, only four lawsuits of any type against Bennett in Provincial Court. One was the successful suit for recovery of a debt of $£ 92.2 .6$ in 1706, two were unsuccessful suits involving land in 1742 and 1746, and one was a 1705 case of an unspecified nature, which the plaintiff countermanded. See Provincial Court Record, Liber TB2, folios 110 and 222; Liber PL1, folio 247; Liber EI7, folio 124; Liber EI10, folio 261, MSA. In Chancery Court, only two suits named Bennett as a defendant. The court dismissed one suit in 1720 with costs paid by the complainant. The court dismissed the other suit in 1726 at the complainant's request. See Chancery Court Record, Liber 3, folios 533 and 631; Liber 4, folio 141. It is, of course, possible that Bennett did borrow money and paid his debts on time, obviating the need for lawsuits.

${ }^{32}$ Bennett in the period from 1697 to 1715 administered the American estate of merchant John Howell of England. In addition, he also became the executor of the estate of merchant John Hunt of Philadelphia in 1707 and the administrator of the estate of Peregrine Browne of London in 1713. Testamentary Proceedings, Liber 19C, folio 149, MSA; Testamentary Proceedings, Liber 22, folios $6,89,119,328$, and 331, MSA; and Provincial Court Land Records, Liber TP4, folio 300, MSA.

${ }^{33}$ The agreement gave Bennett and Heath the right to all quitrents, fines, forfeitures, and arrearages; Bennett and Heath were to pay $£ 500$ sterling annually from 1699 to 1707 and produce new rent rolls. See Provincial Court Land Records, Liber TL2, folios 13-17, MSA; and Arch.Md., XXVII, 37-38 and 154-56.
} 
the 1690s, the Catholic leaders for the most part left active opposition in the hands of the Quakers, who enjoyed better connections in England. In 1704, however, two events beyond their control forced Catholic leaders into action: the beginning of Queen Anne's War and the arrival of a new governor, John Seymour. Seymour, an Anglican and longtime military officer, came to Maryland with instructions to deny toleration to Catholics-instructions that he zealously obeyed. ${ }^{34}$

Immediately after Seymour's arrival, at the April-May session of the Assembly, Bennett's brother-in-law Henry Lowe lost his seat in the lower house for failing to subscribe to the required oaths. Then the lower house considered legislation that would have prevented Catholics from proselytizing among Protestants. Bennett's Protestant half brother Philemon Lloyd II may have been responsible for delaying consideration of this measure, since he chaired the Committee of Laws. However, in the elections held that summer, neither Philemon Lloyd nor Bennett's brother-in-law Richard Tilghman won reelection to the lower house. ${ }^{35}$

In the fall, Governor Seymour directly attacked Catholic worship. In September, the Council summoned two priests to appear and answer charges that one of them had consecrated an altar and the other had said Mass at St. Mary's City while court was in session. Seymour subjected the priests to a long harangue and closed the Catholic chapel in St. Mary's City. ${ }^{36}$ Three weeks later, the Assembly passed "An Act to prevent the Growth of Popery within this Province," which made it illegal for priests to celebrate Mass publicly or privately or to perform any other priestly functions. The legislation also banned Catholics' efforts to convert Protestants, forbade priests to baptize the children of non-Catholic parents, and barred Catholics from teaching school. ${ }^{37}$

Maryland's Act to prevent the Growth of Popery was much milder than the act by a similar name that the English Parliament had passed in 1699;

${ }^{34}$ David W. Jordan, “"Gods Candle' within Government: Quakers and Politics in Early Maryland," William and Mary Quarterly, 3d Ser., XXXIX (October 1982), 648-51; BDML, II, 726; and Instructions for John Seymour, May 4, 1703, PRO CO 5/726: 200 (photocopies at the Library of Congress).

${ }^{35}$ Arch. Md., XXIV, 382-85; BDML, II, 535, 542, 548, and 830. Edward Lloyd II served in the upper house.

${ }^{36}$ Arch.Md., XXV, 178 and XXVI, 44-46. Catholic historian Gerald P. Fogarty, S. J., suggests that the dismissal of the charges against the priests, Robert Brooke and William Hunter, may have been the result of a plea bargain in which wealthy Protestants used their influence to mitigate the anti-Catholicism of the lower classes. (Fogarty, "Property and Religious Liberty in Colonial Maryland Catholic Thought," Catholic Historical Review, LXXII [October 1986], 585n54). However, Seymour himself asserted that he did not want to let the priests have a jury trial, since "a Jury might mistake and acquitt them and so give them Occasion of tryumphing." See Seymour to the Earl of Nottingham, September 29, 1704, PRO CO 5/721: 2-3 (photocopies at the Library of Congress).

${ }^{37}$ Arch. Md., XXVI, 340-41. 
indeed, the Assembly may have passed the act in an effort to shield Catholics in Maryland from the full effects of the English act. Nonetheless, the act shocked Maryland's Catholics, who were accustomed to worshipping freely and had faced no previous discrimination except exclusion from political office. ${ }^{38}$ They petitioned the Assembly for relief, pointing out that Catholics had suffered as much and worked as hard as Protestants in advancing Maryland's interests and had chosen to settle in Maryland because of the religious freedom it had offered them. ${ }^{39}$

The Assembly accepted their petition and resolved in December 1704 to allow Catholics to celebrate Mass in private houses for eighteen months, until Queen Anne's decision on the matter could be known. The deadline approached without a response from Queen Anne, so Richard Bennett and three other prominent Catholic laymen "on Behalf of themselves and the rest of the Roman Catholicks of this Province" petitioned the Assembly in April 1706 to extend the deadline for another year. The other petitioners were Henry Darnall I, Lord Baltimore's agent and receiver general; Darnall's son-in-law, Charles Carroll the Settler, the proprietary attorney general and clerk of the land office; and James Carroll, Charles Carroll's kinsman and an important merchant. ${ }^{40}$

The lower house agreed to extend the deadline, and for the remainder of Seymour's term as governor, the lower house consistently protected Catholic interests. According to Seymour, the Catholics campaigned vigorously on behalf of candidates willing to favor them and used their control of the land office, which remained in proprietary hands, to reward their supporters. While the Catholics undoubtedly did cultivate support in the lower house, the lower house opposed Seymour on a wide variety of issues, not just those relating to Catholics. ${ }^{41}$ By contrast, the upper

${ }^{38}$ There was some confusion and disagreement in this period over whether English statutes applied in Maryland. Parliament's act made Catholic priests who performed any sacerdotal function and Catholics who taught school liable to perpetual imprisonment for the first offense, not the second, as in Maryland. In addition, the act forbade Catholics from sending their children abroad to be educated in the Catholic faith and imposed a double land tax on Catholics. Also, unlike the Maryland act, the English act disqualified Catholics who did not take the oaths of allegiance and supremacy and the Test oath within six months of tuming eighteen years old from inheriting or buying land. An Act for the further preventing the Growth of Popery, 11 Will. 3, c. 4., Statutes.

${ }^{39}$ The copy of this petition that survives is unfortunately unsigned. However, it is safe to assume that one of the leaders behind this petition was Richard Bennett, given his half brother Edward Lloyd II's service on the Council, his own position as leader of the Eastem Shore Catholics, and his participation in a 1706 petition by Catholics discussed below. See "Copy of a memorial from the Roman Catholics in Maryland to the Assembly there," PRO CO 5/115 (photocopies at the Library of Congress).

${ }^{40}$ Arch.Md.,XXVI, 591-92 (quotation onp. 591); and Donnell MacClure Owings, His Lordship's Patronage: Offices of Profit in Colonial Maryland (Baltimore, 1953), 133, 166, and 169-70.

41 John Seymour to the Board of Trade, August 21, 1706, PRO CO 5/16; John Seymour to the Board of Trade, January 10, 1709, PRO CO 5/727: 143-45; John Seymour to the Board of Trade, March 10, 1709, PRO CO 5/727: 151-52 (photocopies at the Library of Congress); Jordan, 
house, appointed by the Crown, was more supportive of Seymour and more hostile to Catholic interests; the upper house balked at the Catholics' petition, complaining that the petition "unhandsomely" charged the Assembly with violating Catholics' freedom and that its tone was more suitable for a challenge than for a petition. The petitioners humbly resubmitted a less assertive petition, and the upper house then graciously acceded to their request. News of Queen Anne's assent to Catholics' worship in private homes reached Maryland in April 1707, and for the remainder of the colonial period, Catholics were free to celebrate Mass privately. ${ }^{42}$

The provision that Catholics could worship only in private houses, not publicly, did not actually limit Catholics' opportunities for worship. Families on both shores had long maintained chapels or mass-rooms, and even the Jesuit chapels qualified as private, because they were attached to houses owned not by the Society of Jesus but by individual Jesuits. On the Eastern Shore, the Knatchbulls, Blakes, Seths, and Heaths were among Richard Bennett's friends who maintained chapels. Bennett himself owned the Doncaster-Town and the Sayer chapels. ${ }^{43}$

Governor Seymour died in 1709 and was succeeded by Bennett's half brother Edward Lloyd II, who served as acting governor until 1714. ${ }^{44}$ During these years, and even before Seymour's death, Richard Bennett approached the Assembly with confidence. For example, he joined his half brother Philemon Lloyd II, his brother-in-law Matthew Tilghman Ward, and others in petitioning the upper house concerning the location of the new Talbot County courthouse in 1707. In that same year, the Assembly passed an act that allowed Bennett and James Heath, as farmers of the quitrents, to sue for the recovery of rents owed them after the expiration of their lease. Finally, in 1710, the Assembly inserted a clause into a town development act that specifically protected Bennett from any ill consequences the act might cause. ${ }^{45}$ Being Catholic did not prevent the well-connected Bennett from receiving favorable treatment from the

Foundations of Representative Government, 216; and Beatriz Betancourt Hardy, "Papists in a Protestant Age: The Catholic Gentry and Community in Colonial Maryland, 1689-1776," (Ph. D. diss., University of Maryland at College Park, 1993), 105-25.

${ }^{42}$ Arch. Md., XXVI, 543-51, and XXVII, 18.

${ }^{43}$ Edward B. Carley, The Origins and History of St. Peter's Church, Queenstown, Maryland, 1637-1976 ([Centreville, Md., 1976]), 18-19; Wills, Liber 28, folios 466-81, MSA; Inventories, Liber 3, folios 271-76, MSA; Inventories, Liber 16, folios 488-94, MSA; and Inventories, Liber 43, folios 176-86, MSA.

${ }^{44}$ Owings, His Lordship's Patronage, 120.

${ }^{45}$ Arch. Md., XXVII, 24, 37-38, 154-56, 532, and 565-66. 
legislature; the Lloyds were one of the two most politically powerful families in Maryland. ${ }^{46}$

In early 1715 Richard Bennett had sufficient cause for contentment. Though he and his wife remained childless, they had many relatives, both Protestant and Catholic, and Bennett was well on his way to becoming the richest man in Maryland after almost a decade of peace for Catholics. However, two events in 1715 shattered that peace. The first was the uprising in Great Britain known as "The Fifteen," which attempted to restore the Stuart monarchy by installing James, the Pretender, on the throne of England. The second was the restoration of political control of Maryland to the Calvert family, which was at least partially caused by the conversion to Anglicanism in 1713 of Benedict Leonard Calvert, who became the fourth Lord Baltimore upon his father's death in February 1715. Benedict Calvert died two months later, and his son Charles Calvert became the fifth Lord Baltimore, inheriting the proprietorship of Maryland. ${ }^{47}$

Bennett himself probably did not pay much attention to these events at first. His friend James Heath doubted Bennett would be interested in "The Fifteen," because, as he observed, "Mr. Bennett's attachment to business gives Him very little time to consider of news." 48 Bennett's apparent detachment was not shared by his fellow Catholics, whose spirits soared. ${ }^{49}$ Lord Baltimore gave Charles Carroll the Settler enlarged powers as his agent and receiver general, which encouraged Catholics to hope that they would be restored to their former positions of power. ${ }^{50}$ Meanwhile, some Catholics openly supported the Pretender. In June 1716 several Catholics fired the great guns on Court House Hill in Annapolis to celebrate the Pretender's birthday. Governor John Hart arrested two suspects, who turned out to be innocent of firing the guns but faced stiff fines for drinking to the Pretender's health. Carroll

\footnotetext{
${ }^{46}$ Jordan, Foundations of Representative Government, 157.

${ }^{47} \mathrm{James}$, whose father James II had been ousted in the Glorious Revolution, was known as the "Pretender" and later, after the 1745 Stuart Rebellion, as the "Old Pretender." For the Calverts, see $B D M L$, I, 186-88.

${ }^{48}$ Heath made his observation in a letter to Elizabeth Bennett, Richard Bennett's wife. Heath was then in London and provided many details about "The Fifteen" in his letter, explaining that he wrote to Elizabeth Bennett and not to her husband because of Richard Bennett's lack of interest. James Heath to Elizabeth Bennett, October 18, 1715, Lloyd Papers, MS. 2001, MHS.

${ }^{49}$ Catholics in Prince George's County drank to the Pretender's health and spread rumors of the success of the Stuart rebellion. Governor John Hart responded by ordering the sheriffs to watch Catholics closely and force anyone they suspected of misbehavior to swear an oath of loyalty. See Arch. Md., XXV, 334-36.

so Owings, His Lordship's Patronage, 167.
} 
claimed the fines on behalf of Lord Baltimore. ${ }^{51}$ Hart, however, considered Carroll unqualified to accept the fines and accused him of acquiring his appointment by deception. The Council supported Hart; only Philemon Lloyd II, Richard Bennett's half brother, defended Charles Carroll. The Assembly soon passed an act requiring all officeholders to take oaths that denied both the authority of the Pope and the Catholic doctrine of transubstantiation. ${ }^{52}$

Charles Carroll and the other leading Catholics did not submit meekly. According to Hart, they raised a large amount of money and sent their leaders to England to try to remove Hart as governor. Like other colonial interest groups, the Catholics hoped to use their connections in England to benefit their position in the colonies; they believed the proprietor would support them. However, their efforts proved fruitless, and Lord Baltimore dismissed Carroll from his offices in $1717 .^{53}$

Carroll's removal mollified neither Hart nor the Assembly. In 1718 the Assembly disfranchised Catholics and repealed the 1704 Act to prevent the Growth of Popery, intending that the harsher English penal laws apply to Maryland Catholics. ${ }^{54}$ While the lower house had earlier defended Catholics against Governor Seymour, it did not defend them against Hart; the restoration of the province to the Calverts and the resurgence of support for the Stuart monarchy may have made the Catholics a more threatening presence to members of the Assembly. Meanwhile, virtually all of the members of the upper house were holdovers from the royal period with no interest in protecting Catholics. Fortunately for the Catholic community, the proprietary courts did not enforce the English laws, despite the Assembly's wishes. ${ }^{55}$

The Catholics responded to the legislative assaults on them by continuing their complaints to England, which led Governor Hart to challenge them to cite a single case of persecution. The leading Catholics, probably including Bennett, planned to present a petition to the Assembly in response to Hart's challenge. However, before submitting their petition, they showed it to a Mr. Humphreys, who warned them not to present it

51 The men wrongly arrested for firing the guns and convicted of drinking to the Pretender's health were William Fitzredmond and Edward Coyle. Fitzredmond was Carroll's nephew. Arch. Md., XXX, 372-74; and Provincial Court Judgment Record, Liber VD2, folios 158, and 359-360, MSA.

$\$ 2$ Arch. Md., XXX, 375-79, 415-16, 422-23, and 613-17. Anyone executing an office without taking the oaths was to face a fine of $£ 250$ sterling.

${ }^{53}$ Arch.Md., XXXIII, 120-22; and on colonial interest groups using their English connections, see Alison G. Olson, "Eighteenth-Century Colonial Legislatures and Their Constituents," Journal of American History, LXXIX (September 1992), 545-46.

s4 Arch. Md., XXXIII, 287-89.

ss $B D M L, I, 41-42$; and for cases in which the courts ruled in favor of the Catholics, see Provincial Court Judgment Record, Liber RB2, folios 14-17, and Court of Appeals Judgment Record, Liber MM1, folios 127-40, MSA. 
because it sounded more like a claim of right than a humble address. The Catholics accepted this advice, perhaps recalling the upper house's reaction to their petition in $1706 .{ }^{56}$ Nonetheless, fearing the possibility of complete defeat and ruin, the Catholics also asked the Spanish ambassador in England for a land grant in the Spanish West Indies, so they could leave Maryland if Hart continued as governor. While the ambassador seemed amenable, nothing came of this request. ${ }^{57}$

Meanwhile, Hart himself had grown weary of battle. In August 1719 he received permission to leave Maryland. Before leaving, Hart again challenged Catholics to cite cases of persecution against them. At Hart's instigation, in April 1720 the Assembly subpoenaed thirteen of the leading Catholics, including Richard Bennett, to respond to his challenge. The Catholics failed to appear before the Assembly, which Hart claimed as evidence that there had been no persecution, but the battle was over. ${ }^{58}$ Hart's departure in 1720 brought this acrimonious period in Maryland history to an end.

Lord Baltimore appointed Thomas Brooke as acting governor and Edward Lloyd II as Keeper of the Great Seal. ${ }^{59}$ These appointments can be seen as a triumph for the Catholic party: Thomas Brooke was a former Catholic whose three brothers had become Jesuits, and Edward Lloyd was the half brother of a prominent Catholic, Richard Bennett. ${ }^{60}$ However, the laws against Catholics remained in place, if unenforced.

Harmonious relations between Catholics and Protestants marked the decades after Hart's departure. King George's War in the 1740s and the Stuart Rebellion in 1745 caused only minor problems for Catholics in Maryland: a few Catholics drank toasts to the Stuart Pretender, but the Assembly did not pass any anti-Catholic bills. ${ }^{61}$ During this period of peace, beginning in the 1720 s, Richard Bennett became a patriarchal figure. According to the Maryland Gazette, Bennett's "long Experience and great Knowledge in Business, as well as his known Candor and

\footnotetext{
56 The petition itself does not survive; and the account describing the petition and Humphreys' advice specifically names only Henry Damall II (1682-1759) and James Carroll, but it credits all of the leading Catholics with helping to write the petition. Richard Bennett was probably among them, since he had joined James Carroll and Henry Damall I, father of Henry Damall II, in petitioning the Assembly in 1706 and was called a leading Catholic by the Assembly in 1720. See Arch. Md. XXXIII, 368; and Black Books \#8, folder 43, MSA.

${ }^{57}$ A.D. to Lord Townsend, April 8,1727, PRO CO 5/721 (photocopies at the Library of Congress).

${ }^{58}$ Arch. Md., XXV, 355, and XXXIII, 478-85, 503-4, and 533. The men called to appear were Richard Bennett, Charles Carroll the Settler, James Carroll, Henry Damall II, William Digges, Benjamin Hall, Clement Hill II, Henry Damall of Portland Manor, William Fitzredmond, Henry Wharton, Charles Digges, Peter Attwood, and Nicholas Sewall.

${ }^{59}$ Arch. Md., XXV, 353-55. Edward Lloyd II had died on March 20, 1719, before news of his appointment arrived. $B D M L, \mathrm{II}, 534-35$.

${ }^{50} B D M L, I, 172$.

${ }^{61}$ Provincial Court Judgment Record, Liber EI10, folios 65 and 222-23; and Anne Arundel County Court Judgment Record, Liber IB6, folios 138-43, MSA.
} 
generosity, occasion'd many to apply to him for Advice and Assistance, and none were ever disappointed of what was in his Power ...." He helped people "without regarding of what Party, Religion or Country, they were." ${ }^{62}$ During these years, Bennett held appointive office for the first time in his life.

At home, Richard and Elizabeth Bennett enjoyed additions to their family. While they produced no children of their own, they took two children into their household. The first was Robert Knatchbull, the son of close friends. The Bennetts raised the orphaned Robert from age five and sent him to St. Omers, an English Jesuit school in Flanders. Robert eventually became a Jesuit. ${ }^{63}$ The second child was Elizabeth's niece Ann Rousby, who was born in 1721. Although Ann's parents were still alive, the Bennetts raised her as their own from infancy. It is not clear why Ann's parents allowed the Bennetts to raise her: the Rousbys were not poor, and Ann's father John Rousby II served on the Council from 1721 until his death in 1744. In 1739 Ann married Bennett's nephew Edward Lloyd III. ${ }^{64}$

In addition to the changes in his immediate family, Bennett also experienced changes in his extended family. After the deaths of his half brothers Edward Lloyd II in 1719, James Lloyd in 1723, and Philemon Lloyd II in 1733, Richard Bennett was the only surviving son of Henrietta Maria Lloyd. The younger generation of Lloyds was not yet established; the oldest male, Edward Lloyd III, the son of Edward, was only twenty-one. Bennett became the supervisor of the younger generation, of whom he was clearly very fond. For example, Bennett urged young Edward Lloyd to become a merchant and as an incentive joined him in a partnership; he also insisted that Edward travel to England to receive treatment for a medical problem. ${ }^{65}$

Bennett's concern also extended to the descendants of his sister. For example, Henry Darnall of Portland Manor had married Bennett's

${ }^{62}$ Annapolis Maryland Gazette, October 18, 1749.

${ }^{63}$ Inventories, Liber 3, folio 271, MSA; Provincial Wills, Liber 17, folio 189, MSA; and Geoffrey Holt, St. Omers and Bruges Colleges, 1593-1773: A Biographical Dictionary, Catholic Record Society Publications, Vol.69 (Thetford and Norfolk, Eng., 1979), 1,155; Testamentary Proceedings, Liber 35, folio 30, MSA. Robert was the son of Norton and Frances Knatchbull, who died in 1719 and 1721, respectively. By Frances Knatchbull's will, Robert's sister Mary was to be cared for by Bennett's half sister Alice Lloyd. Mary married James Tuite, a Catholic who became one of Bennett's many business partners. Robert Knatchbull, who became a Jesuit in 1735, made Richard Bennett the trustee of property that Knatchbull gave to his sister Mary in 1738. See Queen Anne's County Land Records, Liber RTB, folio 346, MSA.

4 Ann's mother lived until at least 1728. See $B D M L$, II, 705-6; and Testamentary Proceedings, Liber 34, folios 299-300, MSA.

65 BDML, II, 534-35, 539, and 541-42; Testamentary Proceedings, Liber 27, folio 2, MSA; and Testamentary Proceedings, Liber 34, folios 299-300, MSA. 
niece Elizabeth Lowe, daughter of Bennett's full sister Susanna. Bennett entered into a partnership with Darnall to enable Darnall to better support his family. Although Darnall consistently lost money, Bennett continued to bail him out of financial difficulties. ${ }^{66}$

Bennett also intervened in a dispute involving the family of his brother-in-law Charles Blake. Doctor Charles Carroll, who had not yet renounced his Catholic faith, had married Blake's daughter Dorothy. Blake promised to provide a dowry of $£ 500$ sterling, paying $£ 50$ per year for ten years, but Carroll demanded the $£ 500$ in a lump sum. Richard Bennett tried in vain "to accomodate the affairs between them," but Carroll ended up suing Blake. Although the Chancery Court ruled in Blake's favor, animosity persisted between the Blake family and Carroll until 1733, when both sides agreed to submit their dispute to Bennett's judgment. Bennett's role as an arbitrator in this case underlines his leadership in both his extended family and the Catholic community. ${ }^{67}$

With Robert Knatchbull in holy orders, Ann Rousby married, and his brothers all dead, Richard Bennett was devastated by the death of his wife Elizabeth in April 1740. As Dr. Charles Carroll reported with great concern to Bennett's longtime friend Daniel Dulany the Elder, a prominent Protestant politician who had recently married one of Bennett's nieces, Bennett was "Inconsoleable" and would "neither rest Speak nor take Sustenance." 68 Bennett grew quite lonely and apparently considered moving in with Ann Rousby and Edward Lloyd III, but Lloyd did not have adequate facilities for Bennett's large business. Instead, Bennett's cousin Ann Brooke came to live with him and manage his household affairs. In the years after Elizabeth Bennett's death, Bennett complained in letters to Daniel Dulany that illness sometimes confined him to home. ${ }^{69}$

\footnotetext{
${ }^{66}$ Henry Darnall of Portland Manor was the son of John Darnall (1671-1705) and Eleanor Brooke; and Elizabeth Lowe was the daughter of Susanna Maria Bennett, Richard Bennett's sister, and Henry Lowe. The information about Damall's business dealings with Bennett comes from a 1758-1761 court case in which he tried to escape paying off his debt to Bennett's estate. See Chancery Court Record, Liber 10, folios 188-228. Bennett wisely bequeathed money not to Darnall but in trust to Damall's daughters. See Testamentary Proceedings, Liber 35, folio 15, MSA.

${ }^{67}$ Doctor Charles Carroll to Richard Bennett, April 26, 1733, undated but probably late April/early May 1733, and November 22, 1733; Doctor Charles Carroll to John Blake, May 6, 1733; all of the above in Doctor Charles Carroll of Annapolis Letterbooks, MS. 208, MHS; and Doctor Charles Carroll against Charles Blake, May 1727, Chancery Court Record, Liber 4, folios 177-91, MSA.

6s Doctor Charles Carroll to Daniel Dulany, April 3, 1740, McPherson-Johnson Family Papers, MS. 1714, MHS. Dulany had married Henrietta Maria Lloyd Chew, daughter of Philemon Lloyd II, in 1738. See $B D M L, I, 284-85$.

$\rightarrow$ Testamentary Proceedings, Liber 34, folio 300, and Liber 35, folios 8, 18-19, MSA. Ann Brooke was the daughter of Bennett's cousin Roger Brooke II and eventually brought her little niece Ann Beall into the Bennett household as well. Alice Lloyd, Bennett's half sister, also may have lived with him until her death in 1744. See Doctor Charles Carroll to Richard Bennett, October 8, 1744, Doctor Charles Carroll of Annapolis Letterbooks, Volume 2, folio 77, MS. 208,
} 
While Bennett's home life changed a great deal after 1720, his religious life may have remained much the same. Although Catholics still could not worship publicly, private chapels remained available, including one at Bennett's home. ${ }^{70}$ Bennett also participated in the life of the Catholic community, serving as godfather to at least one Eastern Shore boy, Thomas Wilson, whom Bennett educated at St. Omers, the Jesuit school that he had earlier entrusted with his ward, Robert Knatchbull. ${ }^{71}$ Bennett also apparently ensured that his slaves received instruction in the Catholic faith. ${ }^{72}$

In addition to his religious activities and family responsibilities, Richard Bennett during the last twenty years of his life served the proprietor in several ways. In 1729 Governor Benedict Leonard Calvert had consulted with Bennett, whom he called "a great and knowing trader," over the question of whether it would be better for the proprietor to continue charging an export duty of two shillings per hogshead in lieu of quitrents, as he had since 1717 , or to revert to collecting quitrents, as he had before 1717. Despite Bennett's advice to continue the export duty on the grounds that it was less burdensome to ordinary planters than quitrents, the proprietorultimately decided in favor of collecting quitrents again. However, the governor's solicitation of Bennett's advice is an indication of his stature in the community. ${ }^{73}$

Ironically, Bennett benefited from Lord Baltimore's decision to collect quitrents again. Since the quitrents were the proprietor's private revenue, Lord Baltimore could appoint whomever he wished to collect

MHS. When Bennett's godson Thomas Wilson returned from St. Omers in 1747, where Bennett had sent him to be educated, he too came to live with Bennett, as Bennett mentioned in his will (Testamentary Proceedings, Liber 35, folios 7-8, MSA). For an example of Bennett's complaints to Dulany, see Richard Bennett to Daniel Dulany, April 7, 1746, Lloyd Papers, MS. 2001, MHS.

${ }^{70} \mathrm{In}$ his will, Bennett bequeathed the contents of the chapel at his home to his Catholic nephew Philemon Blake. Testamentary Proceedings, Liber 35, folio 11, MSA.

71 Bennett's godson Thomas Wilson, born in August 1727, was the son of John Wilson, a Catholic who lived on the Eastem Shore and was frequently indebted to Bennett. Bennett paid for Thomas to attend St. Omers from 1737 to 1745. See Holt, St. Omers and Bruges Colleges, 291; and Bennett's will, Testamentary Proceedings, Liber 35, folios 8, 21, and 30, MSA.

${ }^{72}$ In 1755 Edward Lloyd III estimated that there were about three hundred Catholic slaves in the Wye area, including many of his own. See Edward Lloyd to James Hollyday, December 9, 1755, printed in William D. Hoyt Jr., "A Contemporary View of the Acadian Arrival in Maryland, 1755," William and Mary Quarterly, 3d Ser., V (October 1948), 575. Lloyd had inherited many of his slaves from Richard Bennett. The Maryland Jesuits in 1722 urged masters to lead public prayers and spiritual readings for their servants and slaves; Joseph Mosley, the Jesuit who served the Eastern Shore, in 1774 commended the Catholic slaveholders of the area for carefully instructing their slaves in Catholicism. See The Old Record, folios 4-6, Document \#4.5, Archives of the Maryland Province of the Society of Jesus (Special Collections, Lauinger Library, Georgetown University; hereinafter, MPA, GUSC); and Joseph Mosley to his sister Mrs. Dunn, October 3, 1774, Letters of Joseph Mosley GUSC.

${ }^{73}$ Benedict Leonard Calvert to Charles Calvert, fifth Lord Baltimore, October 26, 1729, Arch.Md., XXV, 604 (quotation); and Owings, His Lordship's Patronage, 76. 
them, regardless of the Assembly's efforts to keep Catholics out of office. In 1731 Lord Baltimore commissioned Bennett as rent-roll keeper of both shores, a position he held for two years, after which he served as rent-roll keeper of the Eastern Shore until his death in $1749 .{ }^{74}$ This position allowed Bennett to distribute patronage in the form of minor appointments as receivers of the quitrents in each county. His nephew Edward Tilghman reluctantly accepted an appointment on the advice of friends, since "the Offer came from Mr. Bennett." When Tilghman complained that the office was troublesome, Bennett assured him, as Tilghman later recalled, "that something better shoud be done for me and upon his Death Bed he woud not be easy 'till I went to Annapolis and gott an Appointment to be Rent Roll Keeper." 75

In 1732 Lord Baltimore also appointed Bennett as one of the commissioners to settle a longstanding boundary dispute with Pennsylvania. Due to illness, however, Bennett attended only one meeting of the commission. ${ }^{76}$ Richard Bennett's service to the proprietor in these years makes it clear that his Catholicism, not an unwillingness to serve, prevented him from holding provincial offices, as his Anglican Lloyd brothers did.

Despite Bennett's concern for his family, friends, and church and his service to the proprietor, business continued to occupy most of his time; and it was in the financial realm, as one of Maryland's major merchantplanters, that Bennett truly distinguished himself. Two economic developments particularly marked the period from 1720 to 1749 for Bennett: the depressed tobacco prices of the 1720 s and the bankruptcy of the prominent English merchant Samuel Hyde in 1746. On the whole, Bennett himself prospered enormously throughout these years.

Tobacco prices had been stagnant from the 1680s until about 1715 when they increased. In the 1720 s prices leveled off and in some markets even fell slightly. ${ }^{n}$ In Maryland, the situation grew desperate: bands of planters roamed the countryside in 1728, cutting down tobacco plants in an effort to restrict production. ${ }^{78}$ Meanwhile, a Maryland Catholic, Henry Darnall II, took the lead in trying to solve the problem without government action. At Darnall's urging, London merchants agreed to participate in a complicated scheme designed to ensure that none of the

${ }^{74}$ Owings, His Lordship's Patronage, 176-77.

${ }^{75}$ Edward Tilghman to Stephen Bordley, December 12, 1753, Bordley-Calvert Manuscripts, MS. 82, MHS. Tilghman, the son of Anna Maria Lloyd and Richard Tilghman, was dismissed as rent-roll keeper in 1756 due to incompetence. $B D M L$, II, 820-21.

${ }^{76}$ Joumal of the Proceedings of the Boundary Commissioners, October 7 and 30, 1732, \#302, Calvert Papers, MS. 174, MHS.

$\pi$ John J.McCusker and Russell R. Menard, The Economy of British America, 1607-1789 (Chapel Hill and London, 1985), 120-27.

${ }^{7}$ Aubrey C. Land, Colonial Maryland: A History (Millwood, N. Y., 1981), 141-43. 
London merchants buying tobacco from the Chesapeake would then sell it to the French below a certain price, hoping by this means to keep the price of tobacco from falling. By mid-1729 the agreement had collapsed. Virtually every prominent Marylander regardless of religion, including Richard Bennett, signed a letter to the London merchants, castigating them for violating the agreement. ${ }^{79}$

Throughout the province, the failure of some representatives in the Assembly, especially those from the Eastern Shore, to support legislation to limit the number of tobacco plants that each worker could tend generated great passion and controversy. At a gathering in October 1728, Samuel Perrie, a member of the lower house from Prince George's County, blamed Richard Bennett for James Hollyday's opposition to the bill. Hollyday, who represented Talbot County in the lower house, had married Sarah Covington Lloyd, the widow of Bennett's half brother Edward Lloyd II, and lived just across the Wye River from Bennett. Another person in the crowd responded that he did not think Hollyday was that kind of man and in any case he did not believe "that Esqr Bennett ever Concern'd himself so much in State Affairs as to Endeavour to Sway or Rule the Governmt...." Perrie then replied "that he knew Esqr Bennett wou'd give a Thousand pounds to Subvert the Government, and that there shou'd not be a Tobacco Law." On October 29, 1728, the upper house met to examine the accusation that Bennett had unduly influenced Hollyday. Of the nine councillors present that day, five were related to Bennett: his half brother Philemon Lloyd II; his brothers-in-law John Rousby II, Richard Tilghman, and Matthew Tilghman Ward; and his nephew Nicholas Lowe. The upper house asked the lower house to examine the charges, which the lower house concluded were false. ${ }^{80}$

While Richard Bennett may or may not have influenced James Hollyday against the tobacco law, he was probably not above using his influence with his many officeholding kinsmen to affect legislation. The only direct evidence of this influence is a letter from Bennett to Hollyday in 1736: Bennett urged Hollyday, who had recently been appointed to the Maryland Council but was then in London, to use his influence with the proprietor to prevent the veto of a law for the speedy recovery of small debts. ${ }^{81}$

\footnotetext{
7 Henry Darnall, A Just and Impartial Account of the Transactions of the Merchants in London, for the Advancement of the Price of Tobacco . . . (Annapolis, 1728), Early American Imprint Series, Evans \#3017. Damall advertised A Just and Impartial Account in the January 7 , 1729, issue of the Annapolis Maryland Gazette. The question of the tobacco trade and the London merchants figured prominently in the newspaper for the whole of 1729 . The letter to the London merchants appeared in the May 27, 1729, issue.

${ }^{*}$ See Arch.Md., XXV, 501-3 (quotations on p. 502) and XXXVI, 144-46 and 240; and BDML, II, $643-44$.

${ }^{81}$ Bennett feared that the various officeholders who would lose income as a result of this
} 
Despite the depressed state of the tobacco market, Bennett's empire grew ever larger: he aggressively expanded his landholdings, especially during the 1720s. Bennett's landownership jumped from 26,876 acres and seven town lots in 1720 to 51,244 acres and fifteen town lots by the end of 1734. Bennett clearly preferred to own land in areas that he knew well: of the 47,197 acres he owned at the time of his death, only 890 acres were on the Western Shore; by contrast, he owned 29,222 acres in Queen Anne's County, where he lived, and in neighboring Talbot County. ${ }^{82}$

Bennett also expanded his moneylending activities. In sum, Bennett lent $£ 2,876.6 .10$ sterling, $£ 1,320.14 .2$ current money, $£ 1,072.16$ current silver money, and 160,313 pounds of tobacco on forty-three mortgages from 1719 to $1749 .{ }^{83}$ Bennett's lending through bonds and book debts consistently augmented his income. He became one of the largest lenders in Maryland, judging from the awards he received in Provincial Court. In the period from 1719 to 1749 , Bennett filed seventy-one cases to recover debts, receiving awards of $£ 15,589.1 .0$ sterling, $£ 2,586.16 .2$ current money, $£ 2,790.7 .10$ current silver money, and 208,807 pounds of tobacco. ${ }^{84}$

Bennett continued to profit greatly from trade and shipping. He ran two stores-one at Wye-Town and one at his home plantation-and owned a number of ships on his own or with partners, buying at least nine ships between 1733 and 1748 and sending them chiefly to New England and the West Indies. ${ }^{85}$ As already noted, Bennett's trading partners included his nephew Edward Lloyd III and his nephew-in-law Henry Darnall of Portland Manor. In addition, Bennett's will mentioned partnerships with his kinsmen, Clement Hill III of Prince George's County and Charles Browne, and with James Tuite of Queen Anne's County, and John Wallace. ${ }^{86} \mathrm{He}$ also entered into a partnership known as the Sassafras Company with Daniel Dulany the Elder, James Buchanan of London, and James Paul Heath, son of Bennett's late partner James

act would persuade the proprietor to veto it. Richard Bennett to James Hollyday, July 14, 1736, Hollyday Papers, MS. 1317, MHS.

${ }^{82}$ See the land records of the various counties, MSA.

${ }^{83}$ Provincial Court Land Records, passim, MSA.

4 Provincial Court Record, passim, MSA. Bennett received awards in fifty-two cases. His executors filed an additional twenty-one suits, winning awards of $£ 698.11 .7$ sterling, $£ 1,566.0 .11$ current money, and 46,381 pounds of tobacco in six cases.

es Henry Callister to Robert Morris, August 5, 1747, Henry Callister Papers, Diocesan Archives of the Protestant Episcopal Church, MHS (microfilm at MSA); Clemens, Atlantic Economy, 123-24; Oxford Port of Entry Books, 1372-1, MSA; and "Commission Book, 82," Maryland Historical Magazine, XXVI (June 1931), 139, 143, 146, 148, 247, 252, 256, and 260-62.

${ }^{86}$ Testamentary Proceedings, Liber 35, folios 11, 12, and 17, MSA. Clement Hill III had married Mary Digges, daughter of Charles Digges and Bennett's niece Susanna Maria Lowe; and Charles Browne had married Priscilla Brooke, daughter of Bennett's cousin Roger Brooke II. 
Heath. ${ }^{87}$ Bennett engaged in the slave trade as an equal partner with Gilbert Falconar of Kent County and London, on behalf of John Hyde and Company of London, and also traded animal skins, Indian goods, and guns with Falconar. ${ }^{88}$ Additionally, he acted as an agent for Heneage Robinson of London, John and Samuel Hyde of London, William Matthews of the Leeward Islands, and Thomas Withers and Thomas Harrison of Barbados. ${ }^{89}$ At least five of Bennett's partners-Darnall, Hill, Tuite, and the two Heaths-were Catholics; most of the others were probably Protestant, demonstrating once again Bennett's easy movement in both the Catholic and Protestant communities. ${ }^{90}$

While Bennett seems to have had good relations with most of his trading partners, the son of a deceased partner attacked his reputation in the mid-1740s. Gilbert Falconar had died, and in 1743 Bennett sued his son Abraham Falconar to recover a debt of nearly $£ 400$ sterling from Gilbert Falconar's estate. Abraham Falconar claimed that Bennett had discharged his father from the debt; he also spread rumors that Bennett had deprived his father's widow of her slaves, cattle, and household goods and could hardly be prevailed upon "to leave her a Bed to lye on, and Cowe to Give Milk"-none of which was true. Bennett called Falconar's accusations "a villainous peice of Roguery" and lamented that if Falconar succeeded, "I Do not know, what further may be Attemptd, Against mee." Compounding Bennett's troubles, he was quite ill and could not travel to Annapolis to press his case in the Provincial Court. Bennett's friends Daniel Dulany the Elder and James Calder ably represented him, and the court ruled in Bennett's favor. ${ }^{91}$

Falconar was annoying, but the most costly and disruptive matter involving a trading partner of Bennett's was the bankruptcy of Samuel

\footnotetext{
${ }^{87}$ Heath served as manager of the Sassafras Company. See "State of Accounts of Cargo in Trade, March 6th, 1741" and "Sassafras Trade in Company, September 22nd, 1746" in the Lloyd Papers, MS. 2001, MHS.

s See "Derby Maker for Gilbert Falconar to Richard Bennett, Receipt, November 2nd, 1717"; Gilbert Falconar to Richard Bennett, December 17, 1718; and "Account, 1732," all in the Lloyd Papers, MS. 2001, MHS.

${ }^{9}$ Provincial Court Land Records, Liber PL5, folios 130, 321-22; Liber PL6, folio 373; Liber PL8, folio 176, MSA.

90 Hill's father Clement Hill II and Damall were among the leading Catholics subpoenaed by the Assembly in 1720 in an incident discussed above at note 58 (Arch.Md., XXXIII, 503). James Tuite frequently appeared in the Jesuit records and sent his son Robert to St. Omers (Joseph Mosley's diary, Document \#6.4, MPA, GUSC; and Holt, St. Omers and Bruges Colleges, 267). James Heath's 1732 inventory included a chalice (Inventories, Liber 16, folios 488-94, MSA); his son James Paul Heath ordered that his sons be raised Catholic in a will probated in 1746 (Wills, Liber 25, folios 63-67, MSA).

${ }^{91}$ Richard Bennett to Daniel Dulany, November 8, 1745, (quotations) and April 7, 1746, Lloyd Papers, MS. 2001, MHS. For the case between Falconar and Bennett, see Provincial Court Judgment Record, Liber EI7, folios 311 and 625; Liber EI8, folios 218 and 446; Liber EI10, folios 49, 84, 240, 501, 661, and 1033; Liber EI11, folio 149, MSA.
} 
Hyde of London, who was one of the most important merchants trading to Maryland in the 1730 s and 1740 s. When rumors spread in early 1746 that he was bankrupt, Marylanders panicked. In April, creditors filed thirteen lawsuits against Hyde in Provincial Court. Richard Bennett received the writs as Hyde's representative in Maryland. In September creditors filed seven more lawsuits, including one by Richard Bennett himself, who was by far the biggest creditor; Hyde owed Bennett over $£ 7,700$ sterling. Hyde turned his property over to trustees, including Bennett and several prominent Protestants, to distribute equitably among his creditors. Bennett himself recovered only about one-sixth of the debt owed him by Hyde. ${ }^{92}$

The financial loss caused by Hyde's bankruptcy deeply affected Richard Bennett and was compounded by the difficulties in trade caused by King George's War. The Spanish, in fact, captured one of Bennett's ships. When Henry Darnall of Portland Manor wrote to Bennett begging for financial help in 1746, Bennett responded that he would do what he could, but he sadly noted that it was no longer "in my power to hold my friends" by rescuing them from financial trouble as he had previously done. Nonetheless, Bennett arranged the consignment of two cargoes of European goods and one of West Indian goods to Darnall in the next three years. ${ }^{93}$

In 1749, during the last months of Richard Bennett's life, he continued, according to his nephew Edward Lloyd III, to "personally transact a great variety of business with the greatest Exactness and Advantage to his own Interest." 94 When Bennett heard that the vestrymen of Suffolk Parish of Nansemond County in Virginia, where his grandfather Richard Bennett I had lived, were misusing a bequest made by his grandfather to benefit

\footnotetext{
92 John and Samuel Hyde appointed Bennett their attomey in Maryland in 1729; see Provincial Court Land Records, Liber PL6, folio 373, MSA. Samuel Hyde in his own right and as executor of the estate of his father John Hyde appointed Bennett attorney in 1732; see Provincial Cour Land Records, Liber PL8, folio 176, MSA. For the various lawsuits, see Provincial Court Record, Liber EI10, folios 173-182, 216, 241, 400, 499, 543, and 545. The other trustees were George Plater, Henry Damall, Benjamin Tasker, Josiah Middlemore, Philip Thomas, and Henry Massey. The trustees took out an advertisement in the Annapolis Maryland Gazette on March 30,1748, to explain the settlement to Hyde's creditors.

${ }^{93}$ Richard Bennett to Henry Darnall of Portland Manor, June 10,1746, rough draft in Chancery Court Record, Liber 10, folio 198, MSA. The Spanish captured one of Bennett's ships, the Hopewell, in 1742, but the British Navy quickly recaptured it and took it to Charles Town, South Carolina. Robert Pringle and James Reid, merchants in Charles Town, reclaimed it on Bennett's behalf. Walter B. Edgar, ed., The Letterbook of Robert Pringle (2 vols. paged consecutively; Columbia; S. C., 1972), I, 385-86 and II, 413.

94 Answer of Edward Lloyd, Testamentary Proceedings, Liber 34, folios 290-91, MSA. In the 1740s Bennett entrusted more and more of his business to his nephew Edward Lloyd III. He also relied heavily on John Lockerman Jr., a Catholic who lived with Bennett and apparently acted as his secretary. See Testamentary Proceedings, Liber 34, folio 300, and Liber 35, folios 11 and 22, and Chancery Court, Liber 10, folio 195, MSA.
} 
the poor, he sternly wrote to the rector of the parish and threatened legal action. It was, he observed, "much to be wondred Men in such Stations should have soe little Regard to Oaths Besides Robing the poor in General for which they may Undoubtedly be cauld to Acct and made to Allow for their Neglect and Unfair Actions." 95

By late September, illness had confined Bennett to bed, where he was attended by many relatives and friends. Nevertheless, he fulfilled his duties as rent-roll keeper and conducted business. He sent com to Virginia, a shallop loaded with goods to a fellow merchant, and settled accounts with the Jesuits, whose demands he disputed but paid anyway, because, he said, he "would not die in Debt." 96

On September 29, Bennett dictated his will to his nephew Edward Tilghman, leaving substantial bequests to a number of his relatives. To those relatives whom he considered irresponsible, he left property in trust. He provided handsomely for his godson. He remembered his business partners and the priests who attended him with bequests. To his overseers and the offspring of his former overseers he gave property. To his slaves he gave suits of clothing and to one, his freedom. He honored his grandfather's memory by leaving all of his property in Virginiaeighty-three slaves - to the parish where his grandfather had lived. He forgave the debts of over one hundred and sixty debtors, big and small, Catholic and Protestant. And finally he left the bulk of his estate to his nephew Edward Lloyd III. Twelve days after signing his will, Richard Bennett died. ${ }^{97}$

Richard Bennett's life demonstrates an essential quality of gentlemen: leadership. Some gentlemen were political leaders, but Bennett was not. He was interested in political matters when they touched either his

\footnotetext{
${ }^{95}$ Richard Bennett Ihad left three hundred acres to Nansemond Parish, which later became Suffolk Parish. See Richard Bennett to the Reverend John Mackenzie, June 19, 1749, and Edward Lloyd III to the Reverend John Mackenzie, January 5, 1750, Suffolk Parish Vestry Book 1749-1784, pages 7 and 4 (photocopy, Virginia State Library, Richmond; hereinafter VSL).

${ }_{96}$ Testamentary Proceedings, Liber 34, folios 290-97, MSA (quotation on folio 296). The Jesuit accounts related to expenses Bennett incurred sending his godson Thomas Wilson to the Jesuit school at St. Omers.

${ }^{77}$ For Bennett's will, see Testamentary Proceedings, Liber 34, folios 441-43, and Liber 35, folios 1-34, MSA. For his Virginia estate, see "Inventory of the Estate in Virginia formerly belonging to Richard Bennett Esq. taken by George Parker in the year 1750," Suffolk Parish Vestry Book 17491784, page 9, photocopy, VSL. Some of Bennett's relatives challenged his will. The dispute was between the mostly Catholic descendants of Bennett's full sister Susanna Maria Damall Lowe and the mostly Protestant descendants of his Lloyd half-siblings. Bennett left substantial legacies to many of his Catholic relatives, but the bulk of his estate went to a Protestant, Edward Lloyd III. On October 26, 1749, Henry Damall of Portland Manor entered a caveat in the Prerogative Court to be notified when the witnesses to Bennett's will were examined, thus beginning legal proceedings to block the will. Two of the witnesses to his will testified that he was not of sound mind: Richard Archbold, a Jesuit priest, testified that Bennett was then "in an Incapacity of Complying with Spiritual Duties," and James Tuite, a Catholic merchant and one of Bennett's
} 
religious or economic interests, but political office was not available to him. Bennett was, however, a leader. He served as a leader of the Catholic community in Maryland by providing chapels, acting as a trustee for the Jesuits, settling disputes between Catholics, and fighting the penal laws. The Assembly acknowledged his leadership position in the Catholic community when it called him to appear in 1720 . Bennett was also one of the leaders of a large and influential family-the Lloyds and their kin. He helped raise his siblings after his mother's death and helped his nephews and nieces in every way that he could: raising Ann Rousby, joining Edward Lloyd III in a partnership, appointing Edward Tilghman collector of the quitrents, and repeatedly bailing Henry Darnall of Portland Manor out of financial trouble.

Finally, Bennett was also an economic leader. He was one of the largest landowners in the province and the greatest trader, according to his obituary, which was an opinion shared by Governor Benedict Leonard Calvert in 1729. In view of the awards Bennett received in debt cases in the Provincial Court, he certainly must have been one of the larger creditors in Maryland. The governor consulted him on a question relating to proprietary finances; he joined other prominent Marylanders in trying to improve the price of tobacco in the late 1720s; he was a trustee for Samuel Hyde when Hyde went bankrupt. For Richard Bennett, being an economic leader meant using his wealth to help others, regardless of their religion. He believed it to be his responsibility to help those in financial trouble, to "hold his friends," as he wrote in the mid-1740s. He rebuked the vestrymen in Virginia who robbed the poor, noting they would be called to account for their behavior, gentlemen, in Bennett's view, would not behave in such a way. In his will, he distributed his wealth widely and forgave the debts of many people. Richard Bennett's tremendous wealth and humanity earned him notice; the Maryland Gazette did not usually report on illnesses, but when Bennett fell sick in September 1749, it was newsworthy.

The case of Richard Bennett suggests that historians need to reconsider the ways in which they identify the gentry. If one is studying economic status, inventories are useful; if one is studying political status, lists of officeholders are useful. If, however, one is studying the gentry,

\footnotetext{
partners, agreed that Bennett was not mentally competent. The other four witnesses swore that Bennett was of sound mind. The case dragged on for several years, but eventually the court ruled that the will signed by Bennett would stand. Transcripts of the case are in Testamentary Proceedings, Liber 33, folios 39, 111, and 113, Liber 34, folios 276-443, and Liber 35, folios 1-45, MSA. Richard Archbold's testimony and other matters related to the case can also be found in Testamentary Papers, Box 49, folder 19, MSA.
} 
consulting only inventories or lists of officeholders is inadequate; gentry status is essentially social and depends on a more complex set of factors than simply economic or political status. Richard Bennett did not qualify by many of the formal criteria that historians use when they try to produce lists of gentry: he held no political office, only a relatively minor post within the proprietor's private establishment; he did not serve on the vestry; he did not leave an inventory that would have identified him as the wealthiest man in the province. But Richard Bennett was a gentleman, and most historians would recognize him as such when confronted with his particular case. Many other gentry have escaped notice: Quakers, Catholics, and gentry uninterested in politics do not appear on lists of officeholders, and the very rich did not invariably leave inventories. Historians studying the gentry, especially those interested in gentry interaction, must cast their nets widely, using every possible record to identify the gentry, both political and non political.

The case of Richard Bennett illustrates one way in which the Catholic gentry adapted to its legal disabilities. Bennett was a moderate in terms of accommodation to the anti-Catholic laws. Unlike Doctor Charles Carroll and Henry Damall III, Bennett never gave up his Catholic faith for the sake of holding office; his religion was important to him, and he regarded taking oaths as a serious matter, as demonstrated by his criticism of the Anglican vestry of his grandfather's parish in Virginia for having "soe little Regard to Oaths." While Bennett joined other prominent Catholics in defending Catholic interests, he did not bitterly resist the penal laws as did Charles Carroll the Settler, who aggravated adverse conditions for Catholics in his battle with Governor John Hart. Instead, Bennett took a more accommodating position, reflecting his formative experiences in a Protestant-Catholic household. It is clear that Bennett felt comfortable among Protestants: many of his closest relatives and business partners were Protestants; he joined with Protestants in the drunken revelry at the Talbot County courthouse in 1692; he served with Protestants on the boundary commission and as a trustee for Samuel Hyde; he lent money to and bestowed charity on Protestants as well as on Catholics. Bennett's extensive ties to Protestants gave him influence that distinguished him from other Catholic gentry; Bennett's Protestant connections were unmatched.

That the largest fortunes in colonial Maryland belonged to CatholicsHenry Darnall I, Charles Carroll the Settler and his son Charles Carroll of Annapolis, and Richard Bennett III-is significant. ${ }^{98}$ The exclusion

\footnotetext{
${ }^{98} B D M L$ does not reveal anyone, other than the Lords Baltimore themselves, who owned even half the amount of land that Richard Bennett did, except Henry Damall I. See BDML, I, 251.
} 
of these prominent Catholics from most public offices did not prevent them from accumulating wealth, leading the Catholic community, and pursuing their economic and religious interests in the political arena. The Catholic gentlemen of colonial Maryland did not have access to the same sources of power as their Protestant counterparts did-nonetheless, they took their place among society's leaders.

Charles Carroll the Settler, who is not included in $B D M L$, owned 47,777 acres when he died in 1720 (Hoffman, “'Marylando-Hibernus'," 220). 